\title{
Coordination Properties of Octaethyl- and Octaphenyltetrapyrazino- porphyrazines in Proton-Acceptor Media
}

\author{
Elena A. Kokareva, Oleg A. Petrov, and Ol'ga G. Khelevina ${ }^{\circledR}$ \\ Department of Organic Chemistry, Ivanovo State University of Chemistry and Technology, Ivanovo, 153000, Russia \\ ${ }^{\circledR}$ Corresponding author E-mail: helevina@isuct.ru
}

The interaction of octaethyl- and octaphenyltetrapyrazinoporphyrazines with dimethylsulfoxide was investigated. The structure of proton transfer complexes has been defined. The complex formation of magnesium octaethyltetrapyrazinoporphyrazine was studied in pyridine. Kinetic parameters of the reaction are defined and the assumptions of the reaction mechanism are given.

Keywords: Porphyrazine, $\mathrm{Mg}$ complexes, proton transfer complexes.

\section{Introduction}

Now much attention is paid to the investigation of porphyrazines, which contain different types of heterocycles annelated to the pyrrole rings of the macrocycle. Such compounds display the properties of semiconductors and liquid crystals. They are used as materials for sensory devises and for medicine. The annelation of heterocycles changes not only the properties of porphyrazine reaction center but also creates additional coordination centres on the periphery of molecules. Thus the research of the relationship of their chemical structure and the reactivity in the reactions of different type is important. Central nitrogens of metal-free porphyrazines behave as $\mathrm{N}$-acids and can loose hydrogens in basic media forming mono- and dianions: ${ }^{[1,2]}$

$$
\begin{aligned}
& \mathrm{H}_{2} \mathrm{Pz} \stackrel{K_{a 1}}{\rightleftarrows} \mathrm{HPz}^{-}+\mathrm{H}^{+} \\
& \mathrm{HPz} \stackrel{K_{a 2}}{\rightleftarrows} \mathrm{Pz}^{2-}+\mathrm{H}^{+}
\end{aligned}
$$

In [3] the UV-vis spectra of porphyrazine acid ionization were analyzed on the basis of the "four-orbital" Gouterman's model ${ }^{[4]}$ and the first order perturbation theory. The analysis showed that two components of the absorption $Q$-band should be merge at dianion formation. The calculations of porphyrazines and their dianions model by PPP method predicated that $Q$-band should be shifted hypsochromically. ${ }^{[5]}$

Porphyrazines can be deprotonated in basic solvents forming proton transfer complexes. The proton transfer complexes are $\mathrm{H}$-associates $\left(\mathrm{H}_{2} \mathrm{Pz} \cdots \mathrm{Solv}\right)$ or $\mathrm{H}$-bonded ionic pairs mainly. ${ }^{[6]}$ It was shown that porphyrazines form the H-associates with DMSO with multicenter hydrogen bonding. ${ }^{[7]}$

In electron absorption spectrum unsplit $Q$-band, typical for $\mathrm{D}_{4 \mathrm{~h}}$ symmetry of $\pi$-chromofore, is observed as a result of the removing of two protons from the reaction center by two DMSO molecules.

The theoretical investigations of connection of macrocycle structure and its acid properties were carried out in ${ }^{[3]}$. The semi-empirical method AM1 was used for these investigations. This method is appropriate for theoretical calculations of acidity of weak organic acids in gas phase ${ }^{[8]}$ In accordance to that the strength of acid may be estimated quantitatively as enthalpy of deprotonation. The correlation was established between values of enthalpy of porphyrazines deprotonation in gas phase and constants of their acid dissociation on the first stage in DMSO (titrant tetraalkyl ammonium hydroxide). ${ }^{[3]}$ Using empirical
Хелевина Ольга Григорьевна родилась в 1941 2. В 1973 2. она начала свою научноисследовательскую работу под руководством Б.Д. Березина, а в 1991 г. зашитила докторскую диссертацию «Координационая химия азапорфиринов в неводных растворах». Сейчас является профессором кафедры органической химии ИГХТУ и занимается исследованием координационной химии тетраазапорфиринов.

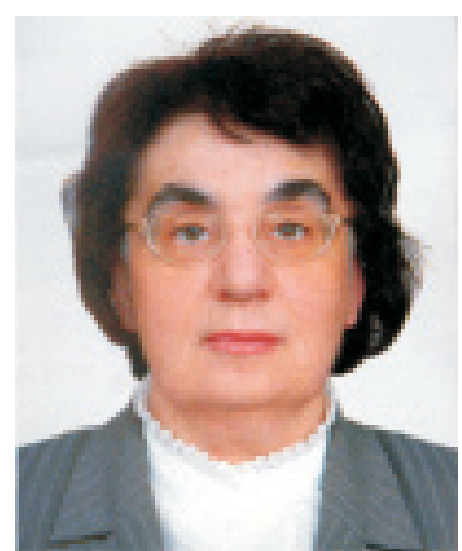

Prof. Khelevina Ol'ga Grigorievna, was born in 1941. She has begun her research work with B.D. Berezin in 1973 and in 1991 received the degree of "Doctor of Chemical Sciences", presenting the dissertation "Coordination chemistry of azaporphyrins in non-aqueous solution". At the moment she is Professor of Organic chemistry department, Ivanovo State University of Chemistry and Technology (ISUCT). Her current research interests are focused on the study of coordination chemistry of tetraazaporphyrins. 
formulas the values of $\mathrm{p} K_{\mathrm{a}}$ were estimated in DMSO on the basis of enthalpy values. ${ }^{[3]}$ In accordance to the calculated $\mathrm{p} K_{\mathrm{a} 1}$ values porphyrazines with annelated heterocycles have much high acidity in DMSO. So the calculated $\mathrm{p} K_{\mathrm{a} 1}$ values equal to 11.23 and 5.82 for the phthalocyanine and tetrapyrazinoporphyrazine accordingly.

Such calculated constants of acidity are in accordance with observing deprotonation of tetrapyrazinoporphyrazine in DMSO solution in the absence of a strong base in contrast to the phthalocyanine. More high acidity of tetrapyrazinoporphyrazine is conditioned by electronacceptor character of pyrazine fragments owing to electronegative inductive and mesomeric effect.

High acidity of tetrapyrazinoporphyrazine allowed to investigate the rare reaction of $\mathrm{Mg}$ incorporation into macrocyclic core. Usually $\mathrm{Mg}$ complexes are obtained by template synthesis.

\section{Experimental}

The octaethyl-(I) and octaphenyl-(II)tetrapyrazinoporphyrazines were prepared according to ${ }^{[9]}$ and were characterized using standard analytical procedures (NMR, IR, UV-vis and elemental analysis). ${ }^{[10]}$

Methylene chloride was distilled over 2-aminoethanol (b.p. $40^{\circ} \mathrm{C}$ ). Glacial acetic acid of chemically pure grade was subjected to repeated freezing and boiling with a calculated amount of acetic anhydride, followed by fractional distillation (b.p. $118^{\circ} \mathrm{C}$ ). Dimethylsulfoxide (DMSO) was maintained during 12 hours over annealed $\mathrm{MgSO}_{4}$ and $\mathrm{CaO}$ and then it was distilled under the reduced pressure. Pyridine was dried over $\mathrm{KOH}$ and then distilled (b.p. $114{ }^{\circ} \mathrm{C}$ ). The magnesium acetate was recrystallized from glacial acetic acid and dried (m.p. $80-85^{\circ} \mathrm{C}$ ).

Acid-base interactions were studied by spectrophotometric titration at $298 \mathrm{~K}$ using Hitachi U-2000 spectrophotometer, following the procedure described earlier. ${ }^{[1]}$ The concentration constants of acid-base interactions $(K)$ were determined by the equation:

$$
\begin{aligned}
& -\lg K=\lg \left(C_{\mathrm{i}} / C_{\mathrm{i}-1}\right)+n \lg C_{\text {DMSO }} \\
& C_{\mathrm{i}} / C_{\mathrm{i}-1}=\left(A_{\infty}-A_{\mathrm{i}}\right) /\left(A_{\mathrm{i}}-A_{0}\right)
\end{aligned}
$$

Here, $A_{0}$ is initial optical density of the solution at analytical wavelength, $A_{\infty}$ is the optical density corresponding to the complete transformation of the porphyrazine into proton transfer complex, $A_{\mathrm{i}}$ is the optical density in $i^{\text {th }}$ run, $n$ is the number of DMSO molecules involved into the acid-base interactions.

To carry out the kinetic measurements the cuvette with porphyrazine solution and magnesium acetate of the known concentration at the set temperature was placed into the cell of Hitachi U-2000 spectrophotometer. The cell was maintained at a constant temperature and optical density was measured at stated intervals on the wavelength, corresponding to the absorption band maximum of the forming complex $(\lambda=639 \mathrm{~nm})$.

Current and initial concentrations of ligand were determined according to the equation:

$$
C=C^{0}\left(A_{\tau}-A_{\infty}\right) /\left(A_{0}-A_{\infty}\right),
$$

where $A_{0}, A_{\tau}$ and $A_{\infty}$ - the optical densities of solutions at the initial moment of time, at the moment of time $\tau$ and after completion of the reaction, $C^{0}$ and $C$ are the current and the initial porphyrazine concentrations.

\section{Results and Discussion}

Acid-Base Interactions of Octaethyl- (I) and Octaphenyltetrapyrazinoporphyrazine (II) with Dimethylsulfoxide

The reactions of acid-base interactions of octaethyl(I) and octaphenyl-(II)tetrapyrazinoporphyrazines with dimethylsulfoxide in dichloromethane were investigated.

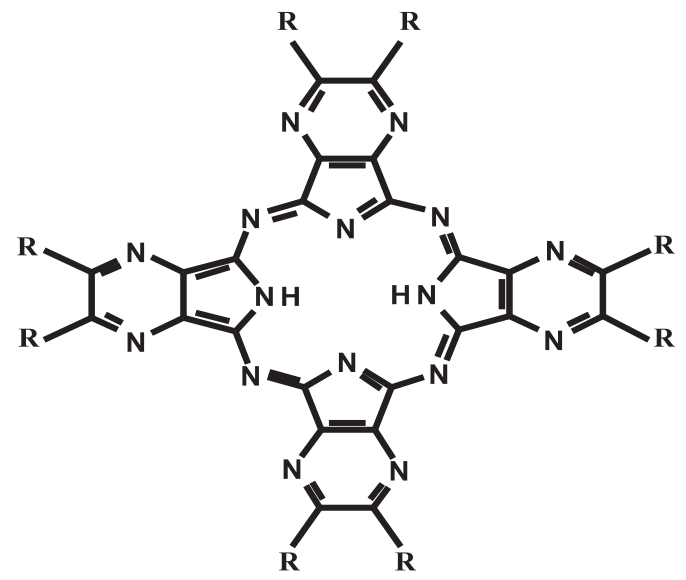

Stucture of tetrapyrazinoporphyrazine
\[ \mathrm{R}=\mathrm{C}_{2} \mathrm{H}_{5}(\text { I }), \mathrm{R}=\mathrm{C}_{6} \mathrm{H}_{5}(\text { II }) \]

The electron absorption spectra of octaethyl- (I) and octaphenyl-(II)tetrapyrazinoporphyrazines in $\mathrm{CH}_{2} \mathrm{Cl}_{2}$ have two maxima at $615 \mathrm{~nm}\left(Q_{\mathrm{x}}\right)$ and $651 \mathrm{~nm}\left(Q_{\mathrm{y}}\right)$ for $(\mathbf{I})$ and $637 \mathrm{~nm}$ $\left(Q_{\mathrm{x}}\right)$ and $669 \mathrm{~nm}\left(Q_{\mathrm{y}}\right)$ for (II). The addition of DMSO reduces the intensity of these bands. The intensity of $Q_{\mathrm{y}}(615 \mathrm{~nm})$ for (I) and $Q_{\mathrm{y}}(637 \mathrm{~nm})$ for (II) is decreased during the spectrum changes in the range of DMSO concentration from 0.014 to $2.76 \mathrm{M}$ and from 0.07 to $1.76 \mathrm{M}$ respectively. In the electron absorption spectrum of the compounds unsplitted $Q$-band is observed, what is typical for $\mathrm{D}_{4 \mathrm{~b}}$ symmetry, in contrast to the splitted $Q$-band in neutral solvents. For compound (I) $Q$-band has maximum at $640 \mathrm{~nm}$, for a compound (II) $Q$-band has maximum at $657 \mathrm{~nm}$ (Figures 1, 2).

The number of DMSO molecules involved into the acid-base interactions was determined as a slope of linear dependences of $\lg \left(C_{\mathrm{i}} / C_{\mathrm{i}-1}\right)$ vs. $\lg C_{\mathrm{DMSO}}$ and equals to $1.87(\mathbf{I})$; 1.80 (II), that is $\approx 2$ (Figures 3,4 ). Thus it was established that proton transfer complexes ( $\left.\mathrm{H}_{2} \mathrm{Pz} \cdots 2 \mathrm{DMSO}\right)$ are formed upon the interaction of tetrapyrazinoporphyrazines with DMSO.

$$
\mathrm{H}_{2} \mathrm{Pz}+2 \mathrm{DMSO} \rightleftarrows \mathrm{H}_{2} \mathrm{Pz}^{-\cdots 2 \mathrm{DMSO}}
$$

To prove the structure of proton transfer complexes a reaction of their interactions with acetic acid has been carried out. Into the solutions of tetrapyrazinoporphyrazines in DMSO $100 \%$ acetic acid was added. The intensities of the $Q$-bands at $641 \mathrm{~nm}$ for I and at $660 \mathrm{~nm}$ for II were decreased. $Q$-band is splited into two components $Q_{\mathrm{x}}=646 \mathrm{~nm}$ and 665 $\mathrm{nm}$, and $Q_{\mathrm{y}}=634 \mathrm{~nm}$ and $645 \mathrm{~nm}$ for the compounds I and II respectively. The spectrum changes in the range of acetic acid concentration from 0.044 to $0.874 \mathrm{M}$ for $\mathbf{I}$, and from 0.087 to $2.63 \mathrm{M}$ for II are presented in Figures 5, 6. On the basis of experimental and calculation data linear dependences 


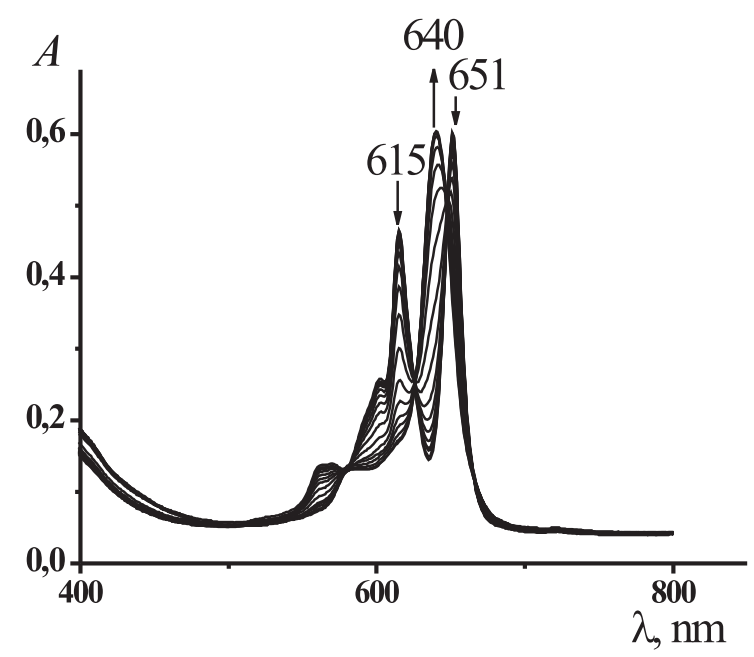

Figure 1. Spectral changes during the interaction of octaethyltetrapyrazinoporphyrazine with DMSO in $\mathrm{CH}_{2} \mathrm{Cl}_{2}$.

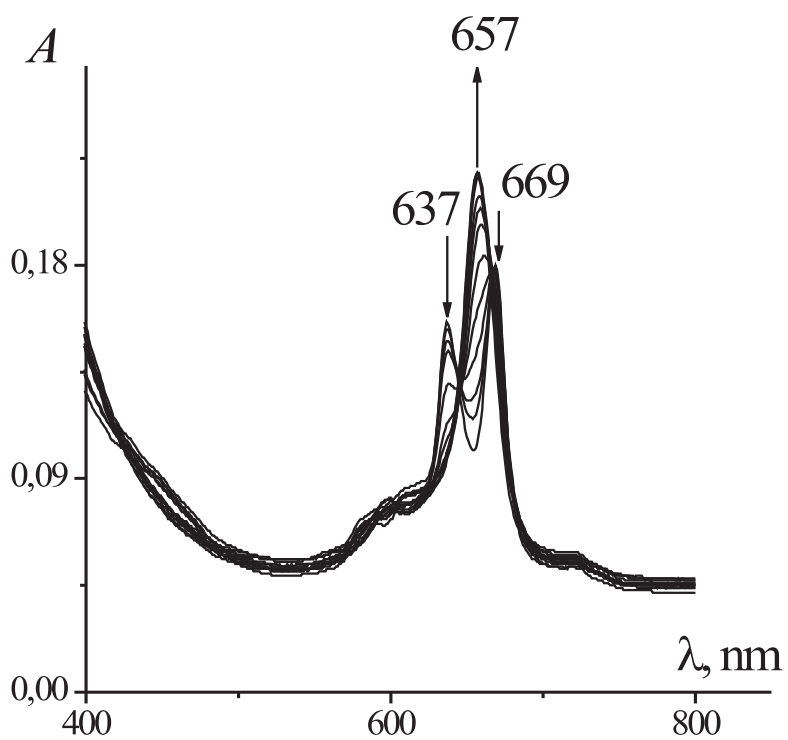

Figure 2. Spectral changes during the interaction of octaphenyltetrapyrazinoporphyrazine with DMSO in $\mathrm{CH}_{2} \mathrm{Cl}_{2}$.

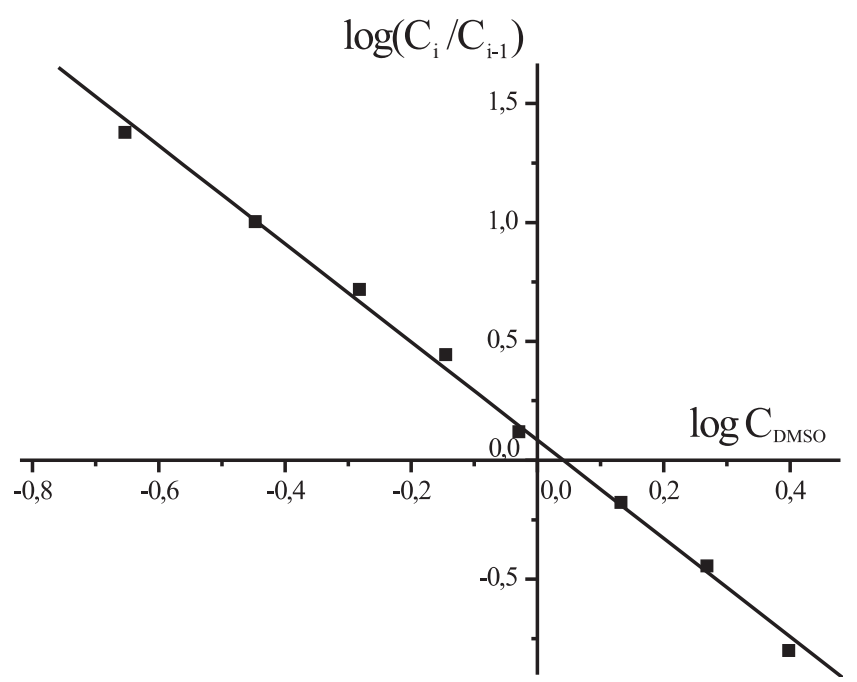

Figure 3. The plot of $\lg \left(C_{\mathrm{i}} / C_{\mathrm{i}-1}\right) v s \cdot \lg C_{\mathrm{DMSO}}$ for acid-base interactions of octaethyltetrapyrazinoporphyrazine with DMSO in $\mathrm{CH}_{2} \mathrm{Cl}_{2}$ at $C_{\text {DMSO }}=0.014-2.76 \mathrm{M}$.

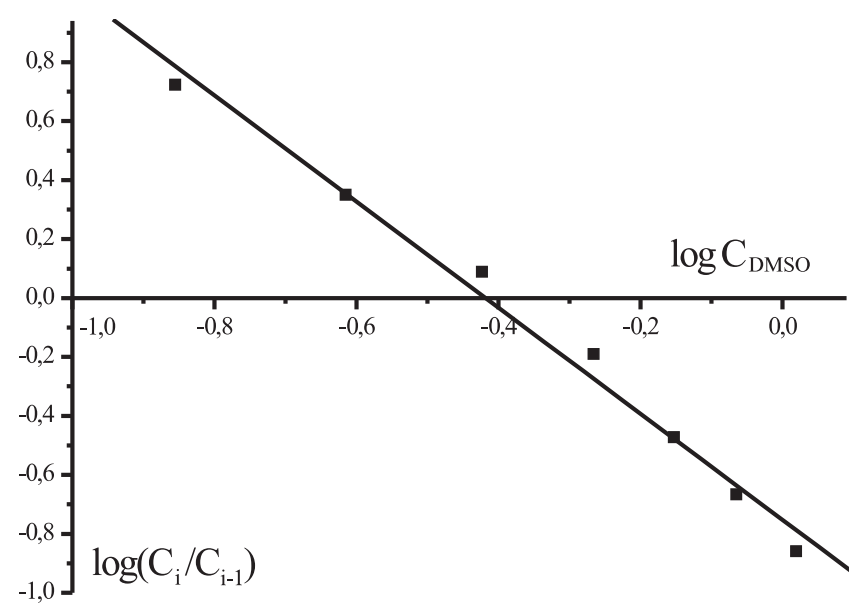

Figure 4. The plot of $\lg \left(C_{\mathrm{i}} / C_{\mathrm{i}-1}\right) v s . \lg C_{\mathrm{DMSO}}$ for acid-base interactions of octaphenyltetrapyrazinoporphyrazine with DMSO in $\mathrm{CH}_{2} \mathrm{Cl}_{2}$ at $\mathrm{C}_{\text {DMSO }}=0.07-1.76 \mathrm{M}$

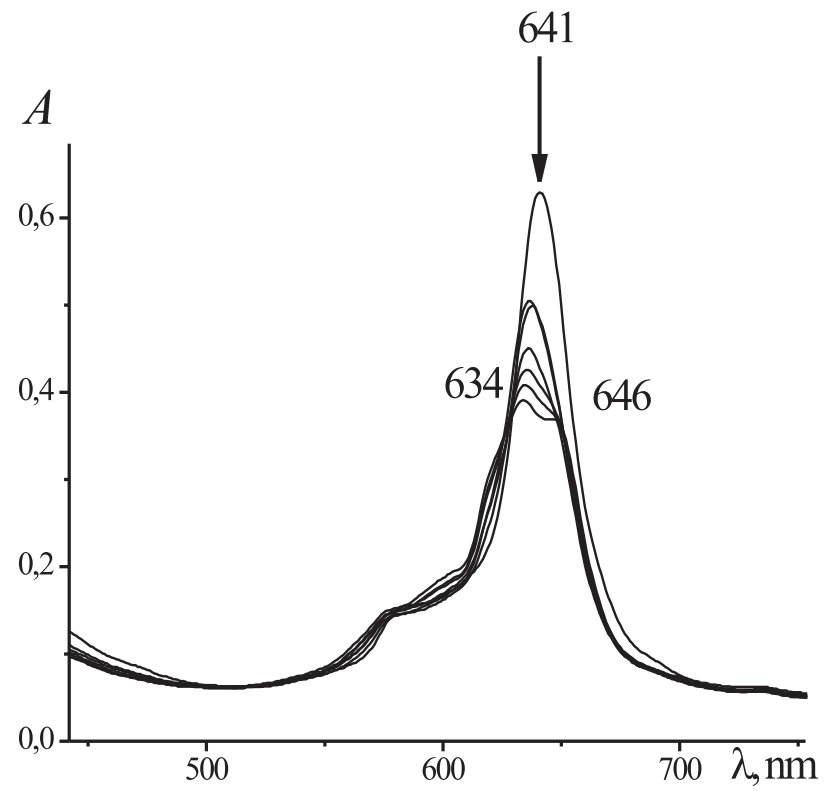

Figure 5. Spectral changes of $\mathrm{H}_{2} \mathrm{Pz} \cdots 2 \mathrm{DMSO}$ for compound $\mathbf{I}$ in $\mathrm{CH}_{3} \mathrm{COOH}-\mathrm{DMSO}$.

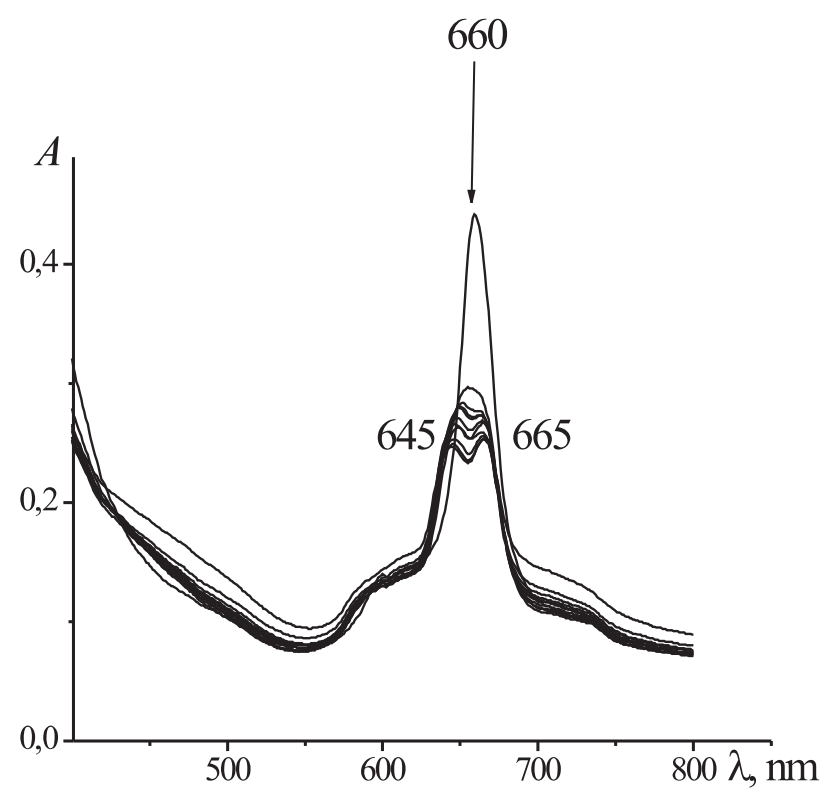

Figure 6. Spectral changes during $\mathrm{H}_{2} \mathrm{Pz} \cdots 2 \mathrm{DMSO}$ for compound II in $\mathrm{CH}_{3} \mathrm{COOH}$-DMSO. 


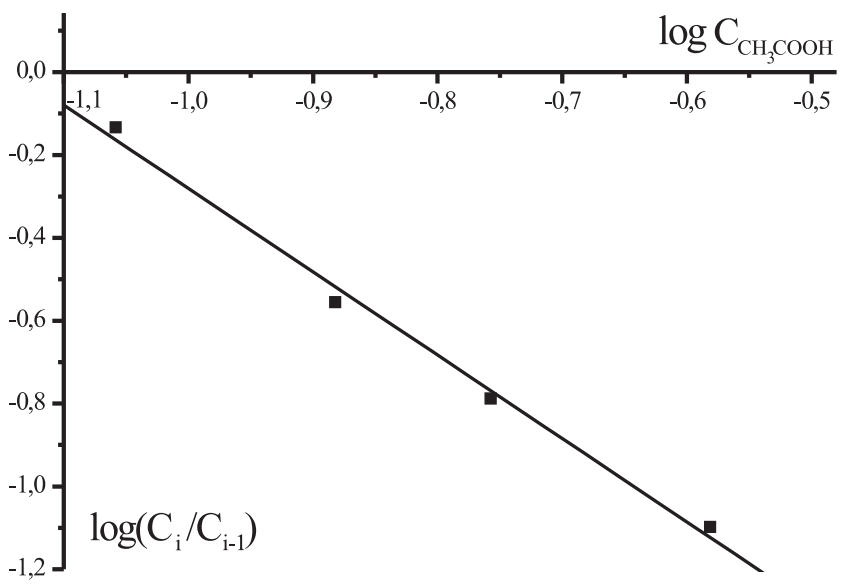

Figure 7. The plot of $\lg \left(C_{\mathrm{i}} / C_{\mathrm{i}-1}\right)$ vs. $\lg C_{\mathrm{CH}_{3} \mathrm{COOH}}$ for acid-base interactions of $\mathrm{H}_{2} \mathrm{Pz} \cdots 2 \mathrm{DMSO}$ for compound $\mathbf{I}$ in $\mathrm{CH}_{3} \mathrm{COOH}-$ DMSO at $\mathrm{C}_{\mathrm{CH}_{3} \mathrm{COOH}}=0.044-0.874 \mathrm{M}$.

$\lg \left(C_{\mathrm{i}} / C_{\mathrm{i}-1}\right)$ vs. $\lg C_{\mathrm{CH}_{3} \mathrm{COOH}}$ were obtained with the slope of 2. Thus, two molecules of acetic acid take part in the acidbase interactions. The $\mathrm{p} K$ values for the studied equilibrium were determined as $1.14 \pm 0.02$ for $\mathbf{I}, 0.45 \pm 0.02$ for II (Figures 7, 8).

$$
\begin{aligned}
& \mathrm{H}_{2} \mathrm{Pz} \cdots 2 \mathrm{DMSO} \stackrel{K}{\rightleftarrows} \mathrm{H}_{2} \mathrm{Pz}+2 \mathrm{DMSO} \\
& \mathrm{DMSO}+\mathrm{CH}_{3} \mathrm{COOH} \rightleftarrows \mathrm{DMSO}\left(\mathrm{CH}_{3} \mathrm{COOH}\right.
\end{aligned}
$$

The very small additions of acetic acid into the octaethyltetrapyrazinoporphyrazine solution in DMSO (from 0.001 to $0.03 \mathrm{M}$ ) lead to the hypsochromic shift of $Q$-band on $5 \mathrm{~nm}$ and the growth of its intensity (Figure 9).

The data of spectrophotometric titration (Figure 10) show that one molecule of acetic acid is involved into acidbase interactions.

$$
\begin{aligned}
& \mathrm{H}_{2} \mathrm{Pz} \cdots 2 \mathrm{DMSO} \stackrel{K_{1}}{\longleftarrow} \mathrm{H}_{2} \mathrm{Pz} \cdots \mathrm{DMSO}+\mathrm{DMSO} \\
& \mathrm{DMSO}+\mathrm{CH}_{3} \mathrm{COOH} \rightleftarrows \mathrm{DMSO}\left(\mathrm{CH}_{3} \mathrm{COOH}\right)
\end{aligned}
$$

The $\mathrm{p} K_{1}$ value equals to $1.20 \pm 0.01$. We suppose that the complex with transfer of one proton into DMSO molecule

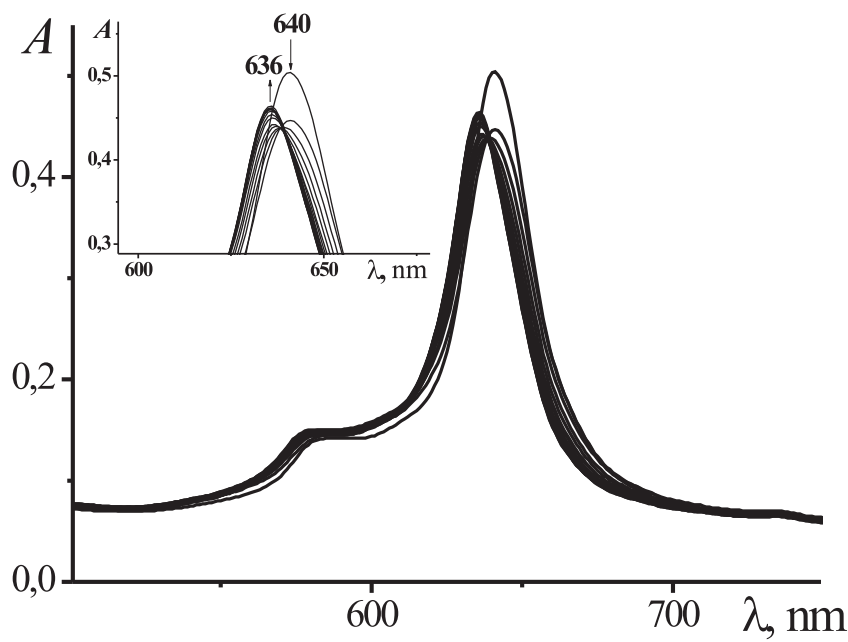

Figure 9. Spectral changes during of $\mathrm{H}_{2} \mathrm{Pz} \cdots 2 \mathrm{DMSO}$ for compound I in $\mathrm{CH}_{3} \mathrm{COOH}-\mathrm{DMSO}$.

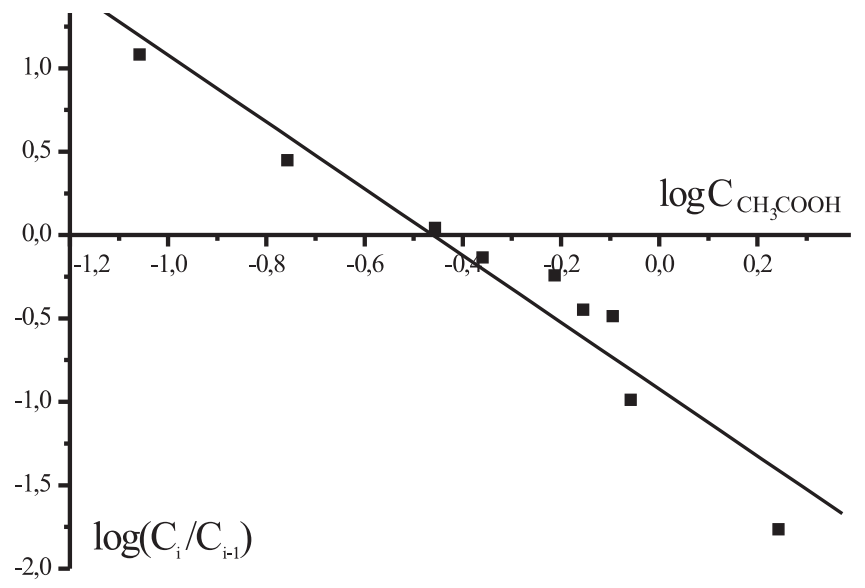

Figure 8. The plot of $\lg \left(C_{\mathrm{i}} / C_{\mathrm{i}-1}\right)$ vs. $\lg C_{\mathrm{CH}_{\mathrm{COOH}}}$ for acid-base interactions of $\mathrm{H}_{2} \mathrm{Pz} \cdots 2 \mathrm{DMSO}$ for compound II in $\mathrm{CH}_{3} \mathrm{COOH}-$ DMSO at $\mathrm{C}_{\mathrm{CH}_{3} \mathrm{COOH}}=0.087-2.63 \mathrm{M}$

is formed at this stage. Its Uv-vis spectrum is similar to that of complex with transfer of two protons into DMSO molecules.

On the basis of the data ${ }^{[12]}$ the electron absorption spectrum of one proton transfer of $\beta$-octa $(N$-methylpyridine4-yl)porphyrazine complex differs greatly by $Q$-band width and by less intensity from that of two proton transfer complex. A similar fact has been discovered for octaethyltetrapyrazinoporphyrazine by us.

With an increase of acetic acid quantity a neutral form of porphyrazine is formed very quickly, i.e. equilibrium is displaced to the formation of the ligand and the determination of $\mathrm{p} K_{2}$ value was impossible.

$$
\begin{aligned}
& \mathrm{H}_{2} \mathrm{Pz} \cdots \mathrm{DMSO} \stackrel{K_{2}}{\rightleftarrows} \mathrm{H}_{2} \mathrm{Pz}+\mathrm{DMSO} \\
& \mathrm{DMSO}+\mathrm{CH}_{3} \mathrm{COOH} \rightleftarrows \mathrm{DMSO}\left(\mathrm{CH}_{3} \mathrm{COOH}\right)
\end{aligned}
$$

Thus, it is possible to assume, that overall equilibrium constant of process of DMSO molecules splitting for compound $\mathbf{I}(\mathrm{p} K=1.14)$ is an equilibrium constant of one DMSO molecule splitting ( $\left.\mathrm{p} K_{1}=1.20\right)$.

It was impossible to carry out a similar experiment for octaphenyltetrapyrazinoporphyrazine because of association process in high acidity media.

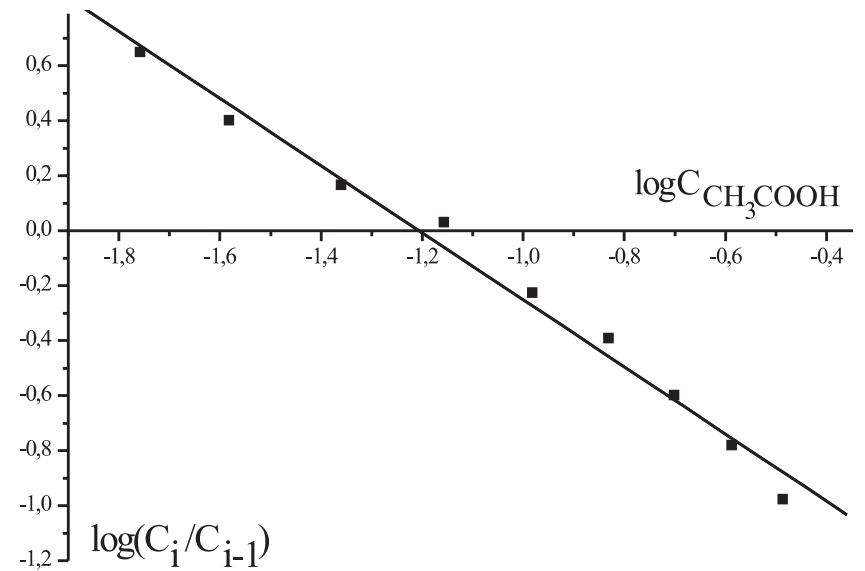

Figure 10. The plot of $\lg \left(C_{\mathrm{i}} / C_{\mathrm{i}-1}\right)$ vs. $\lg \mathrm{C}_{\mathrm{CH}_{\mathrm{COOH}}}$ for acid-base interactions of $\mathrm{H}_{2} \mathrm{Pz} \cdots 2 \mathrm{DMSO}$ for compound $\mathbf{I}$ in $\mathrm{CH}_{3} \mathrm{COOH}$ DMSO at $C_{\mathrm{CH}_{3} \mathrm{COOH}}=0.001-0.03 \mathrm{M}$. 
Complexation of Octaethyltetrapyrazinoporphyrazine with Magnesium(II) Acetate in Pyridine

The porphyrazines react with metal salts in basic media forming chelate complexes. ${ }^{[6]}$ The high acidity of $\mathrm{NH}$ bonds in reaction centre of porphyrazines allows to investigate the rare reaction of $\mathrm{Mg}$ incorporation. Usually complexes of porphyrins and $\mathrm{Mg}^{\mathrm{II}}$ are obtained only by template synthesis. We studied the reaction of octaethyltetrapyrazinoporphyrazine interaction with $\mathrm{Mg}(\mathrm{OAc})_{2}$ in pyridine, but not in DMSO, since the formation of proton transfer complexes in DMSO hesitates to study the reaction. Octaethyltetrapyrazinoporphyrazine does not form the proton transfer complexes with pyridine in the conditions of complex formation (Figure 11).

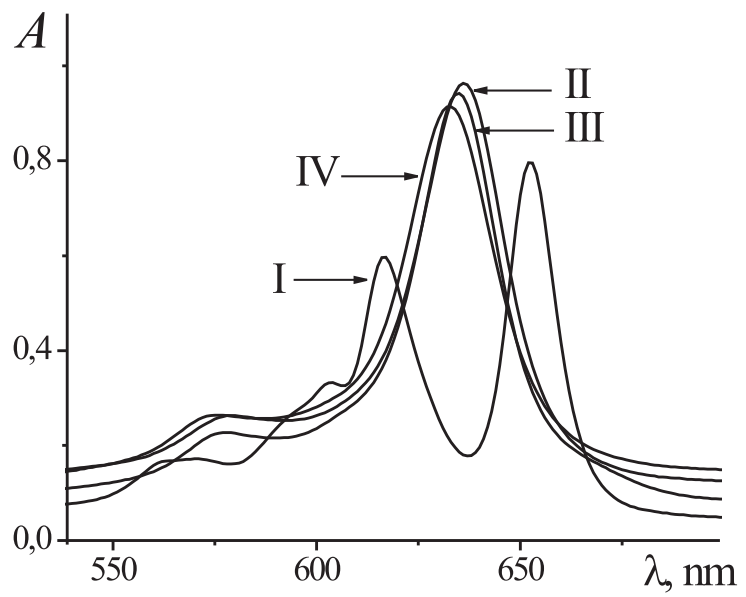

Figure 11. The electron absorption spectrum of octaethyltetrapy razinoporphyrazine: I $\left(\lambda_{\mathrm{I}} 651 \mathrm{~nm}, \lambda_{\mathrm{II}} 615 \mathrm{~nm}\right)$ and of complexes: II - Mg ( $\left.\lambda_{\text {max }} 639 \mathrm{~nm}\right)$, III - Zn $\left(\lambda_{\text {max }} 636 \mathrm{~nm}\right), \mathrm{IV}-\mathrm{Cu}\left(\left(\lambda_{\max }\right.\right.$ $633 \mathrm{~nm}$ ) in pyridine.

Complex formation reaction between porphyrazines and magnesium acetate in pyridine proceeds according to the following equation:

$\mathrm{H}_{2} \mathrm{Pz}+\left[\mathrm{Mg}(\mathrm{Py})_{6}\right](\mathrm{OAc})_{2} \rightarrow \mathrm{MgPz}+2 \mathrm{HOAc}+6 \mathrm{Py}$

The inner coordination sphere of $\mathrm{Mg}^{\mathrm{II}}$ ion in pyridine is formed by six pyridine molecules and acetate anions are in the outer coordination sphere: $\left[\mathrm{Mg}(\mathrm{Py})_{6}\right](\mathrm{OAc})_{2}{ }^{[6]}$

Figure 12 displays changes in the UV-vis spectra of porphyrazine $\mathbf{I}$ in the presence of $\mathrm{Mg}(\mathrm{OAc})_{2}$ in pyridine. The reaction proceeds in a large excess of the metal salt, i.e. in pseudo-first-order conditions. The linear dependences of $\lg C_{\mathrm{H}_{2} \mathrm{Pz}}$ on the reaction time indicate that the reaction of magnesium complex formation has the first order by porphyrazine (Figure 13). The observed rate constants $\left(k_{\mathrm{obs}}\right)$ can be calculated from the following equation:

$$
k_{\text {obs }}=\frac{1}{\tau} \ln \frac{\mathrm{C}_{\mathrm{H}_{2} \mathrm{Pz}}^{0}}{\mathrm{C}_{\mathrm{H}_{2} \mathrm{PZ}}}, \mathrm{s}^{-1}
$$

The kinetic parameters of $\mathrm{Mg}$ complex formation are given in Table 1. The experimental data show that the observed rate constants are almost independent in respect to the salt concentration.

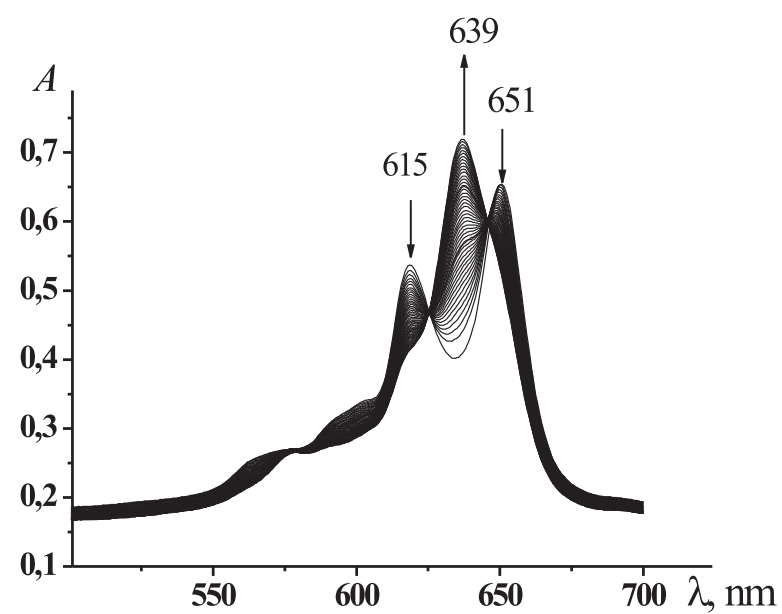

Figure 12. Spectral changes of octaethyltetrapyrazinoporphyrazine during the process of complex formation with $\mathrm{Mg}(\mathrm{OAc})_{2}$ in pyridine.

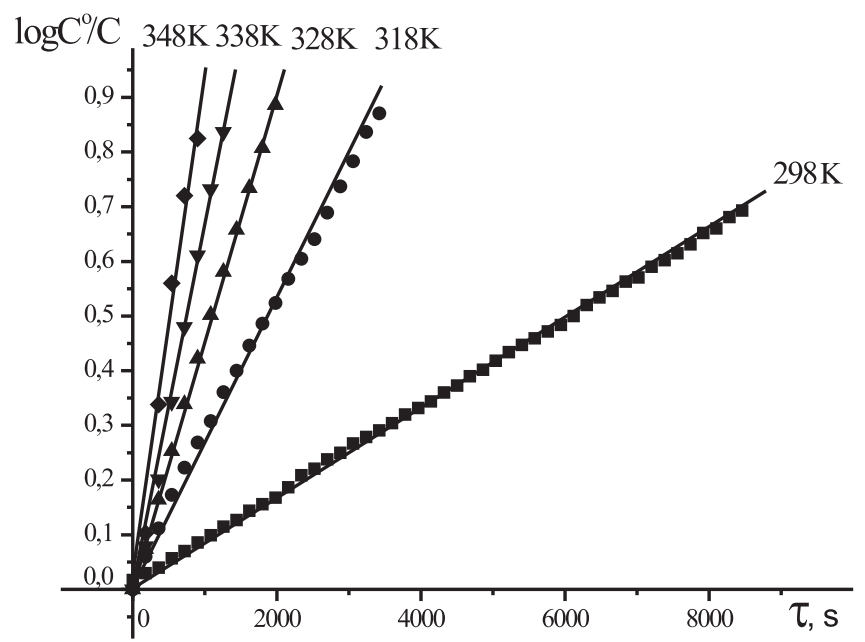

Figure 13. The plot of $\lg C^{0} / C v s$. time $\tau$ (s) for the reaction of $\mathrm{Mg}$ octaethyltetrapyrazinoporphyrazine complex formation.

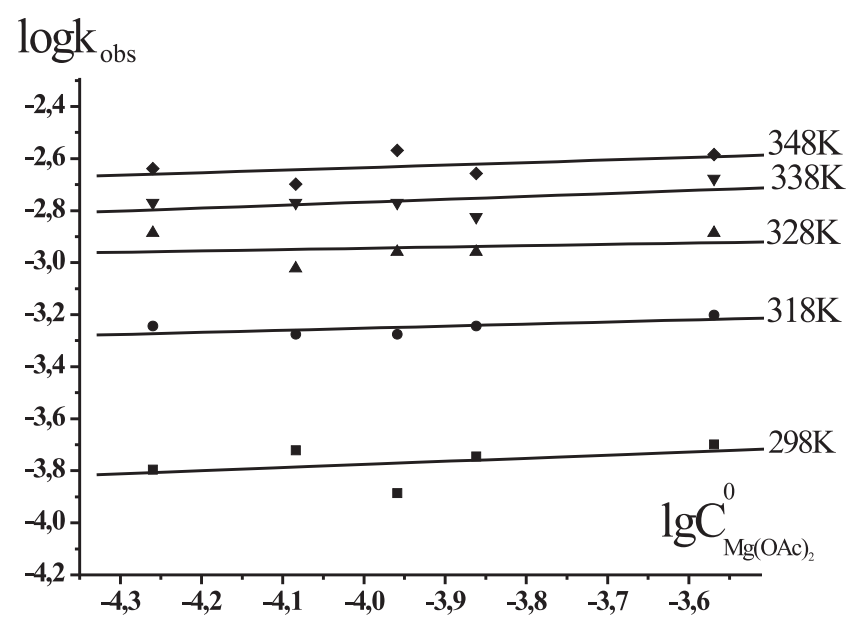

Figure 14. The plot of $\lg k_{\text {obs }} v s . \lg C^{0} \mathrm{Mg}(\mathrm{OAc})_{2}$ for $\mathrm{Mg}$ complex formation reaction in pyridine.

The reaction order in magnesium acetate (calculated as the slope of $\lg k_{\text {obs }} v s . \lg C_{\mathrm{Mg}(\mathrm{OAc})_{2}}$ (Figure 14) is close to zero (the values vary from 0.1 to 0.2 ). Thus, the limiting stage of the complex formation is monomolecular. 
Table 1. Kinetic parameters of $\mathrm{Mg}$ complex formation in pyridine $\left(\mathrm{C}_{\mathrm{H}_{2} \mathrm{Pz}}^{0}=6.02 \cdot 10^{-6} \mathrm{M}\right)$.

\begin{tabular}{|c|c|c|c|c|}
\hline$C_{\mathrm{Mg}(\mathrm{OAc})_{2}}^{0} \cdot 10^{4}, \mathrm{M}$ & $\mathrm{T}, \mathrm{K}$ & $k_{\mathrm{obs}} \cdot 10^{3}, \mathrm{~s}^{-1}$ & $E, \mathrm{~kJ} / \mathrm{mol}$ & $\Delta S, \neq \mathrm{J} /(\mathrm{mol} \cdot \mathrm{K})$ \\
\hline \multirow{5}{*}{0.55} & 298 & $0.16 \pm 0.01$ & \multirow{5}{*}{$44 \pm 2$} & \multirow{5}{*}{$-178 \pm 6$} \\
\hline & 318 & $0.57 \pm 0.01$ & & \\
\hline & 328 & $1.30 \pm 0.01$ & & \\
\hline & 338 & $1.70 \pm 0.01$ & & \\
\hline & 348 & $2.31 \pm 0.01$ & & \\
\hline \multirow{5}{*}{0.83} & 298 & $0.19 \pm 0.02$ & \multirow{5}{*}{$40 \pm 4$} & \multirow{5}{*}{$-190 \pm 12$} \\
\hline & 318 & $0.53 \pm 0.04$ & & \\
\hline & 328 & $0.95 \pm 0.25$ & & \\
\hline & 338 & $1.70 \pm 0.01$ & & \\
\hline & 348 & $2.01 \pm 0.04$ & & \\
\hline \multirow{5}{*}{1.10} & 298 & $0.13 \pm 0.04$ & \multirow{5}{*}{$51 \pm 7$} & \multirow{5}{*}{$-156 \pm 22$} \\
\hline & 318 & $0.53 \pm 0.04$ & & \\
\hline & 328 & $1.10 \pm 0.01$ & & \\
\hline & 338 & $1.70 \pm 0.01$ & & \\
\hline & 348 & $2.70 \pm 0.03$ & & \\
\hline \multirow{5}{*}{1.38} & 298 & $0.18 \pm 0.01$ & \multirow{5}{*}{$42 \pm 2$} & \multirow{5}{*}{$-184 \pm 6$} \\
\hline & 318 & $0.57 \pm 0.01$ & & \\
\hline & 328 & $1.10 \pm 0.01$ & & \\
\hline & 338 & $1.51 \pm 0.02$ & & \\
\hline & 348 & $2.20 \pm 0.02$ & & \\
\hline \multirow{5}{*}{2.70} & 298 & $0.20 \pm 0.03$ & \multirow{5}{*}{$43 \pm 2$} & \multirow{5}{*}{$-180 \pm 6$} \\
\hline & 318 & $0.63 \pm 0.06$ & & \\
\hline & 328 & $1.30 \pm 0.01$ & & \\
\hline & 338 & $2.11 \pm 0.04$ & & \\
\hline & 348 & $2.60 \pm 0.02$ & & \\
\hline
\end{tabular}

The octaethyltetrapyrazinoporphyrazine has the strong electron-acceptor pyrazine fragments, which favors the delocalization of negative charge in the deprotonated form of the ligand and leads to the dianion $\mathrm{Pz}^{2-}$ formation in the transition state. If dianion is formed, then owing to its high complexation reactivity one should expect a monomolecular reaction and the dissociative mechanism. ${ }^{[6]}$ Thus the complexation of octaethyltetrapyrazinoporphyrazine is supposed to occur through the stage of dianion formation as follows:

$$
\begin{aligned}
& \mathrm{H}_{2} \mathrm{Pz}+2 \mathrm{Py} \rightarrow \mathrm{Pz}^{2-}+2 \mathrm{PyH}^{+} \\
& \mathrm{Pz}^{2-}+\left[\mathrm{Mg}(\mathrm{Py})_{6}\right](\mathrm{OAc})_{2} \rightarrow \mathrm{MgPz}^{2} 2 \mathrm{AcO}^{-}+6 \mathrm{Py}
\end{aligned}
$$

The limiting stage of the reaction is dianion formation. The high complexation reactivity of the dianion is confirmed

Table 2. The observed rate constants of $\mathrm{Mg}$ complexes formation

\begin{tabular}{|c|c|}
\hline Porphyrazine & $k_{\mathrm{obs}}{ }^{298}, \mathrm{~s}^{-1}$ \\
\hline Tetraazaporphine, $\mathrm{H}_{2}$ TAP & $0.96 \cdot 10^{-8}$ \\
\hline Octaphenyltetraazaporphine, $\mathrm{H}_{2} \mathrm{TAPPh}_{8}$ & $0.01 \cdot 10^{-4}$ \\
\hline $\begin{array}{l}\operatorname{Octa}(n \text {-bromophenyl)tetraazaporphine, } \\
\qquad \mathrm{H}_{2} \mathrm{TAP}\left(\mathrm{C}_{6} \mathrm{H}_{4} \mathrm{Br}_{8}\right)\end{array}$ & $0.0098 \cdot 10^{-4}$ \\
\hline $\begin{array}{c}\text { Octa(n-sulfamoilphenyl)tetraazaporphine, } \\
\mathrm{H}_{2} \mathrm{TAP}\left(\mathrm{C}_{6} \mathrm{H}_{4} \mathrm{SO}_{2} \mathrm{NHC}_{18} \mathrm{H}_{37}\right)_{8}\end{array}$ & $0.41 \cdot 10^{-4}$ \\
\hline $\begin{array}{c}\text { Octaethyltetrapyrazinoporphyrazine, } \\
\mathrm{H}_{2} \mathrm{Pz}_{\left(\mathrm{Et}_{8} \mathrm{Pyz}_{4}\right)}\end{array}$ & $1.72 \cdot 10^{-4}$ \\
\hline
\end{tabular}
in pyridine. by interaction of octaethyltetrapyrazinoporphyrazine with $\mathrm{Zn}^{\mathrm{II}}$ and $\mathrm{Cu}^{\mathrm{II}}$ salts. These reactions proceed almost in a moment at $298 \mathrm{~K}$ (Figure 11). Therefore we could investigate only the reaction of $\mathrm{Mg}$ incorporation.

The observed rate constants of $\mathrm{Mg}$ complexes formation in pyridine are given in Table 2 .

According to the published data $^{[13]}$ and our experimental data the rate of complex formation increases in the series:

$$
\begin{aligned}
& \mathrm{H}_{2} \text { TAP }<\mathrm{H}_{2} \mathrm{TAPPh}_{8} \approx \mathrm{H}_{2} \mathrm{TAP}\left(\mathrm{C}_{6} \mathrm{H}_{4} \mathrm{Br}_{8}\right)< \\
& \mathrm{H}_{2} \mathrm{TAP}\left(\mathrm{C}_{6} \mathrm{H}_{4} \mathrm{SO}_{2} \mathrm{NHC}_{18} \mathrm{H}_{37}\right)_{8}<\mathrm{H}_{2} \mathrm{Pz}\left(\mathrm{Et}_{8} \mathrm{Pyz}_{4}\right) \text {. }
\end{aligned}
$$

This series shows that the coordination rate of octaethyltetrapyrazinoporphyrazine with $\mathrm{Mg}$ ions is higher than for other porphyrazines. This is due to the increasing of the NH bonds acidity owing to electron-acceptor character of pyrazine fragments.

\section{Conclusion}

In proton-acceptor medium $\mathrm{CH}_{2} \mathrm{Cl}_{2}-\left(\mathrm{CH}_{3}\right)_{2} \mathrm{SO}$ tetrapyrazinoporphyrazines can undergo two steps of acid ionization with the formation of proton transfer complexes, containing two molecules of DMSO ( $\left.\mathrm{H}_{2} \mathrm{Pz} \cdots 2 \mathrm{DMSO}\right)$. It is found that the splitting of two DMSO molecules from proton transfer complex proceeds stepwise in acid medium.

The reaction of complex formation of magnesium with octaethyltetrapyrazinoporphyrazine in pyridine was studied and its kinetic parameters were determined. The scheme of the reaction mechanism is proposed. 


\section{References}

1. Stuzhin P.A. J. Porphyrins Phthalocyanines 1999, 3, 500514.

2. Sheinin V.B., Berezin B.D., Khelevina O.G., Stuzhin P.A., Telegin F.Yu. Zh. Org. Khim. 1985, 21, 1571 (in Russ).

3. Stuzhin P.A. J. Porphyrins Phthalocyanines 2003, 7, 813

4. Gouterman M. J. Mol. Spectrosc. 1961, 6, 138.

5. Kobayashi N., Konami H. J. Porphyrins Phthalocyanines 2001, 5, 233.

6. Stuzhin P.A., Khelevina O.G. Coord. Chem. Rev. 1996, 147, 41.

7. Petrov O.A. Diss. Doct. Chem. Sci., Ivanovo, ISUCT, 2006, 264 p. (in Russ).

8. Dewar M.J.S., Dieter K.M. J. Am. Chem. Soc. 1986, 108, 8075 .
9. Shishkin V.N. Diss. kand. khim. nauk, Ivanovo, ISUCT, 2006 (in Russ).

10. Lebedeva T.A., Kulinich V.P., Kudrik E.V., Shaposhnikov G.P., Kozlova A.V. In: Tezisy Mezhdunarodnoy Conferentsii "Organicheskaya Khimiya ot Butlerova $i$ Beil'shteina do Sovremennosti» [Abstract Book of Int. Conf. "Organic Chemistry from Butlerov and Beilstein to the Present»] St. Petersburg, 2006, 254 p. (in Russ).

11. Albert A., Serjeant E. Ionization Constants of Acids and Bases London: Methuen, 1962.

12. Anderson M.E., Barrett A.G.M., Hoffman B.M. Inorg. Chem. 1999, 38, 6143.

13. Khelevina O.G., Rumyantseva S.V. Uspekhi Khimii Porfirinov [Advances in the Porphyrin Chemistry], St. Peterburg: NII Khimii. Sankt-Peterb. Gos. Univ., 2004, 4, 128 (in Russ).

Received 06.06.2009 Accepted 25.06.2009 